\title{
Achieving optimal tomato production levels using the downstream of production
}

\author{
Zul Azhar ${ }^{1}$, Hasdi Aimon ${ }^{2}$, Elida $^{3}$, Zadrian Ardi ${ }^{4}$ \\ 1234 Universitas Negeri Padang, Padang - Indonesia, (zulazhar@fe.unp.ac.id)
}

\begin{abstract}
The productivity and sustainability of the tomato agriculture sub-sector is an essential aspect of tomato production. However, the problem that arises during the production period is the decline in the price of tomatoes during the harvest so as not to benefit the farmers, it affects the demotivation of production and environmental damage if not treated properly. Survey of this research was conducted on 100 tomato farmers in Kenayahan Selayo Tanang Bukik Sileh Solok. The data were processed using the production model and agricultural costs to observe the productivity and sustainability of the tomato agricultural sub-sector. The results showed that the input factor still decreased return to scale and productivity in the economy still need to be improved. The cost side is not economically efficient with low variable cost coefficients. Achievement of tomato production level optimally is done by downstream of tomato products. The scheme of this process is designed in the form of Development Planning Model of Environmentally Produced Tomato Center.
\end{abstract}

Keywords: productivity, sustainability, decreasing return to scale, cost efficiency

\section{Introduction}

One type of vegetable plant that contributes to the development of rural economy is tomato (Barron \& Rello, 2000; Gelcer et al., 2018; Keatinge et al., 2015). The occurrence of harvest condition is indicated by the contribution of tomato production to the total production of vegetables sub-sector is on average reaches $63.2 \%$ (BPS, 2014). This high number causes excess supply in the regional market. Excess supply means high production rather than consumption (Kusadokoro, Kagami, \& Senda, 2016; Yildiz, Duhadway, Narasimhan, \& Narayanan, 2016). Data from Central Statistics of Solok Regency (2014) noted that about $42 \%$ of tomato production exceeds the consumption of tomatoes themselves. The consequence is that the price of tomatoes is cheap, so many unsold tomatoes that many tomatoes become rotten waste. Associated with the behavior of rotten tomato farmers dumped in any place like to the road, ditch and river, thus causing negative externalities to the surrounding community. In addition, many tomato farmers suffered and many of them changed the occupation.

Lembang Jaya Sub-district in Solok often experience the highest harvest condition compared to other sub-districts. The harvest has implications for the high excess supply of tomatoes in this area. This is based on data from BPS Lembang Jaya Dalam Angka (2014) where the excess supply of tomatoes compared with the demand reached $58.3 \%$. This means that for every two tomatoes produced only one sold tomatoes. The high excess supply of tomatoes in this area has made tomato 
farmers in Lembang Jaya suffered the biggest losses due to the harvest that occurred from 2012-2014 compared with tomato farmers elsewhere. The proportion of input use in tomato farming to achieve optimal production and downstream of suitable products for tomato farmers.

Urgency of this paper from the side of tomato farmers lies in how tomato farmers in the process of doing agricultural activities can determine the proportion of input in achieving optimal tomato production output. Furthermore, tomato farmers can calculate the average cost of production and income of farmers so as to realize a prosperous farmers. In addition, the nagari government side through the development planning model of environmentally sound tomato production center can be a nagari program of sustainable development.

\section{Literature Review}

Hoover states that the growth of a region is the result of a complex interaction between various activities of a region's economic activities, so it would be impossible to determine an initial cause of regional growth (Azhar, Zul, 2013). Changes in the region's economy may be independent, may be exogenous or even a cause-and-effect occurrence. However, Hoover at least notes that changes in demand (especially exports of a region) and changes in regional labor supply and factors of production others (such as capital or technological change) are the main drivers of a region's growth.

According to Manyong, the most fundamental constraints to the growth of the agricultural sector are the production system (Brévault \& Bouyer, 2014; Devendra, 2013), the low response to technology adoption (Kumar et al., 2018; Muriu-Ng'ang'a, Mucheru-Muna, Waswa, \& Mairura, 2017; Rattalino et al., 2017), the land fragmentation and the failure of the domestic industry (Daharnis, Ardi, \& Ifdil, 2018; Gbanie, Griffin, \& Thornton, 2018; Len, Oleniacz, Skrzypczak, \& Mika, 2017; Montgomery, Reid, \& Mandrak, 2018; Williams et al., 2017) which increases production risks and may be caused by the uncertainty of the farmers how the farmers can be involved in diversifying products or producing with multilevel companies by adopting specific agro-ecological zones (Ajibefun, 2006; Manyong, V.M.; Ikpi, A.; Olayemi, J.K.; Yusuf, S.A.; Omonona \& V.; Idachaba, 2005). Diversification of the household industry as an agricultural strategy is believed to gain a number of advantages: the ability to reduce risks, improve income and employment opportunities (Amerasinghe, Bhardwaj, Scott, Jella, \& Marshall, 2013; Ardi \& Yendi, 2017; Ardi, Yendi, \& Ifdil, 2013; Lischeid, 2014; Rimos, Hoadley, \& Brennan, 2015; Warziniack, 2014; Williams et al., 2017), the ability to reduce disease and awareness and improve soil fertility (Singh, 2000). Bamji suggests that diversification in the household / fund industry or between household industries and the improvement of animal husbandry security, particularly for marginal and poor farmers (Bamji, 2000).

Production is the end result of the process of economic activity by utilizing several inputs (Joesron, 2003: 77). It is understandable that the production activity is a combination of various inputs or inputs to produce output. The technical relationship between inputs and outputs in the form of equations, tables or graphs is a function of production. Meanwhile, Salvatore argues that the production function is the physical relationship between the variables described $(\mathrm{Y})$ and the explanatory variable (X) (Van den Berg, M.M.; Hengsdijk, H.; Wolf, J.; Ittersum, M.K.V.; Guanghuo \& Roetter, 2007). The variables described are usually outputs and variables that explain usually in the form of input. With the production function, the researcher can know the relationship between production factor (input) and production (output) directly and the relationship can be more easily understood. Besides with production function, researcher can know relation between explanatory variable. Mathematically, this relationship can be explained as follows (Salvatore, 2007) $: Y=f\left(X_{1}, X_{2}, \ldots, X_{n}\right)$. The production function has properties such as utility functions. If the input increases, the output also increases. But the addition of the first input will provide an additional output greater than the additional output 
caused by additional subsequent input. This property is called law of diminishing return (Case \& Fair, 2007).

Mankiw says that every production process has a technical foundation, which in economic theory is called a production function (Mankiw, 2006). The production function is a function or equation that shows the relationship between the level of output and the level of use of inputs. Graphically, ceteris paribus, the only labor production function (L) (assumed K remains), then $Q(L)$ is as follows:

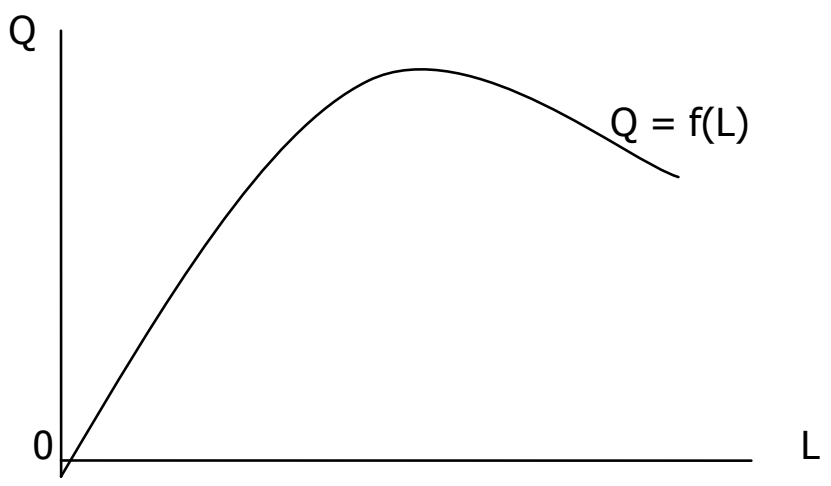

Figure 1: Production Function

Source: Case \& Fair (2007:144)

Mathematically, the nature of the production function increases (if the input increases then the output increases) is indicated by the first derivative $Q$ to $\mathrm{L}$ is positive. Whereas the decreasing nature of the rise (representing the law of diminishing return) is indicated by the second derivative $Q$ against the negative $\mathrm{L}$ (concave curve). Cobb-Douglas production function is a function of equation involving two or more variables. One variable is called dependent, described (Y) and other variables are called independent variables that explain (X) (Bilas, 2008) the settlement of the relationship between $X$ and $Y$ is usually by regression, i.e. variations of $Y$ will be influenced by variations of $X$. The Cobb-Douglas production function is as follows (Bilas, 2008), $\mathrm{Q}=\mathrm{AK}^{\alpha} \mathrm{L}^{\beta} \mathrm{Q}$ is the output quantity and $\mathrm{L}$ and $\mathrm{K}$ are respectively labor and capital goods $\alpha$ (alpha) and $\beta$ (beta) are positive parameters determined by data. The properties of the Cobb-Douglas production function are as follows, $\mathrm{K}$ and L may mutually substitute. If labor becomes expensive, the company will substitute the workforce with capital. In this case, labor-intensive technology is replaced by capital-intensive technology. Substitution between these inputs follows the Marginal Rate of Technical Substitution / Transformation rule described by the isoquant curve. $\frac{\partial Q}{\partial K}, \frac{\partial Q}{\partial L}>0$, the marginal productivity of the factors of production is positive. This formula shows the marginal product of capital and labor is positive. Marginal Product of Capital (MPP) and Marginal Product of Labor (MPL) depend on the level of output and level of capital and labor utilization. $M P K=\alpha \frac{Q}{K}$ dan $M P L=\beta \frac{Q}{L} ; \frac{\partial^{2} Q}{\partial K \partial K}, \frac{\partial^{2} Q}{\partial L \partial L} \quad,<0$, the marginal productivity of its factors of production follows the law of diminishing returns. This trait reflects that Cobb-Douglas's production function is in conjunction with its implications, the function has a maximal value. $Q=(K)^{\alpha}(L)^{\beta}$, is Constant Returns to Scale, if $(\alpha+\beta)=1$. That is, if the $\mathrm{K}$ and $\mathrm{L}$ inputs increase each time to twice, then the output also increases twice. In this case, the output increases proportionally with the addition of the input. Increasing Returns to Scale, if $(\alpha+\beta)>1$. That is, if the inputs $\mathrm{K}$ and $\mathrm{L}$ plus each become two times, then the output also increases more than two times. In this case, the output increases more than the proportion by the input gain. Decreasing Returns to Scale, if $(\alpha+\beta)<1$. That is, if the $\mathrm{K}$ and $\mathrm{L}$ inputs increase each time to twice, then the output increases less than two times. The output increases less than the proportion of input increments. This condition can occur because the complexity of the production process becomes very high if the scale of operation is large. Decreasing 
Returns to Scale implies diseconomies to scale, that is, the average cost increases as the output increases.

Further according to (Altieri A., 1992) Sustainable Agricultural Development in Latin America: exploring the possible. Stating that critical issues of the agricultural sector are addressed to the issue of productivity and sustainability of the agricultural sector in America Latin. His findings suggest that the solution to the problems of the agriculture sector is on new technological innovations, changes in agricultural development policies, and socio-economic conditions in line with farmers' expectations. According to (Yaron, 1998) Alternative Land Use Options in the Mount Cameroon Region: An Economic Analysis, The Center for Social and Economic Research on the Global Environment. His findings state that the economic costs and benefits of alternative land-use options in the lowlands at the foot of Mount Cameroon. Thus, it will increase the total value economically from the side of production, sales, and sustainability of agricultural exports.

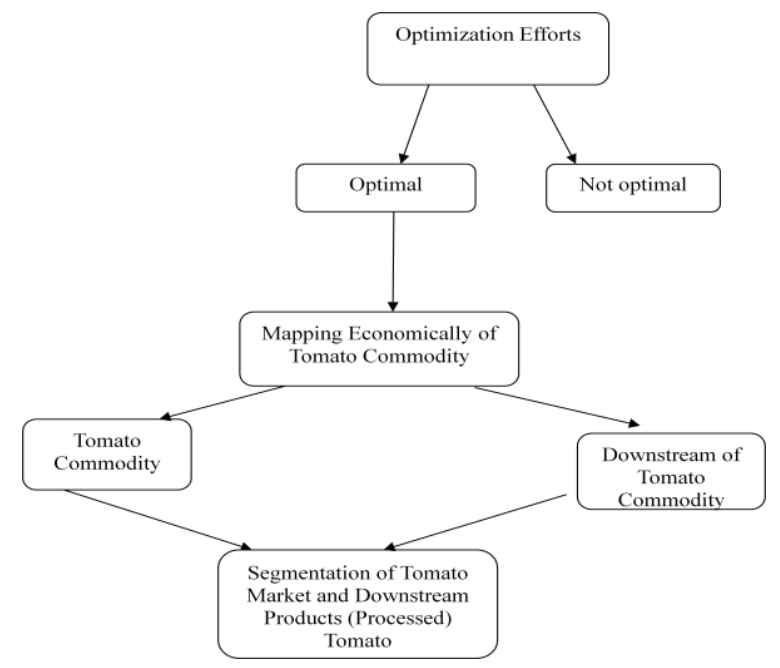

Figure 2 Model Production Function of Cobb-Douglas

Research of tomato with Model Total Production (TP) is Land Area (LL), plus Raw Material (BB) and Fertilizer (PP) as follows;

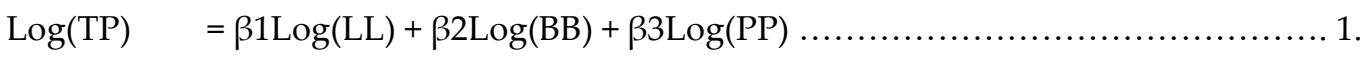

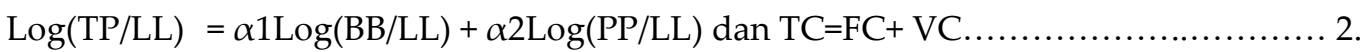

Total tomato production is determined by the variation of input factors in this study determined by; a) land area (LL), b) Seed cost (BB), and c) Fertilizer Fee (PP).

\section{Result and Discussion}

Production of tomatoes that exceed the need (over product) is not utilized, the downstream planning should be made. This if not thought of will make the tomato farmers will lose and make demotivasi to tomato farming. In addition, unsold tomatoes and cannot be consumed will be wasted to rot, so as to create a less healthy environment.

The result of input factor estimation to total tomato production can be seen in Table 1 below. 
Table 1: Estimated Results of Total Tomato Production

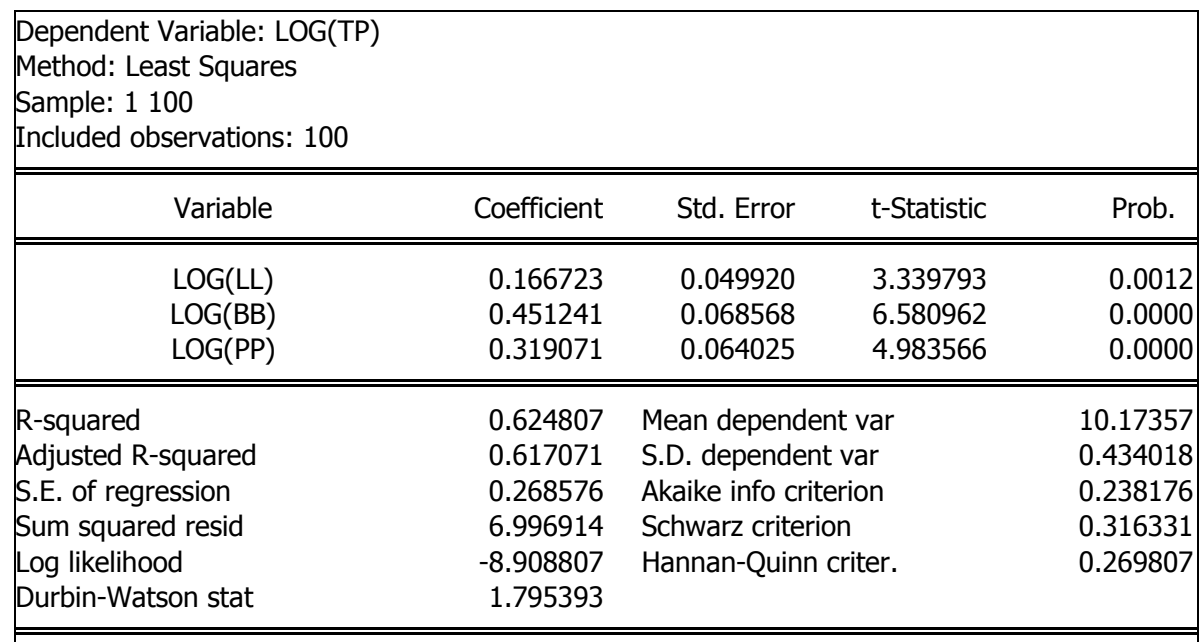

The result of estimation in Table 1 above shows that all input factors have significant effect to total tomato production at alpha 1 percent. The contribution of input factors to total tomato production is 62.48 percent. This means there are other factors that determine the total production of tomatoes that are not scrutinized in this study such as; climate, irrigation system, and other factors by 37.52 percent. The estimation results can also be seen in the form of equations;

$$
\mathrm{LOG}(\mathrm{TP})=0,1667 \mathrm{LOG}(\mathrm{LL})+0,4512 \mathrm{LOG}(\mathrm{BB})+0,3191 \mathrm{LOG}(\mathrm{PP})
$$

Which is:

$$
\begin{array}{ll}
\mathrm{TP} & =\text { Total of Tomato Production } \\
\mathrm{LL} & =\text { Land Area } \\
\mathrm{BB} & =\text { Seed Cost per Planting Period } \\
\mathrm{PP} & =\text { Cost of Fertilizer per Planting Period }
\end{array}
$$

Total tomato production in Nagari Salayo Tanang Bukik Sileh is influenced by the area farmed by farmers and also influenced by the amount of Tomato Seed Cost and fertilizer cost. The results showed that total tomato production was positively influenced by 0.1667 percent of the land area and the cost of seeds of 0.4512 percent and influenced by the cost of fertilizer by 0.3191 percent. This means that if the land area is increased by 1 percent, then the tomato production will increase by 0.1667 percent and if the cost of seed is increased 1 percent, the tomato production will increase by 0.4512 , and if the fertilizer cost is added 1 percent, tomatoes will increase by 0.3191 . So, the determinant input factor is seeds then fertilizer and new land area.

In addition, tomato production in Nagari Salayo Tanang Bukik Sileh indicates that input factors together contribute 0.6248 or $62.48 \%$ to total tomato production. The average tomato production in one planting period is 10.17 tons with a standard deviation of 0.43 . This means showing the tendency of tomato production of Nagari Salayo Tanang Bukik Sileh to be between $9.74-10.17$ tons. So if small tomato production from 9.74 tons in a single planting period, it can be said that the farmer is low level of ability in producing tomatoes as a tomato farmer. Then the elasticity of production factor is still small from 1 that is equal to 0,937. It means still decreasing return to scale (DRTS). Therefore, tomato farmers in Nagari Salayo Tanang Bukik Sileh still need to increase their production capability by coaching and counseling in the development of input factor in order to change into increasing return to scale (IRTS). 
Table 2. Estimated Results of Total Production of Tomato Per Hectare of Land with RTS = 0.7740

\begin{tabular}{|c|c|c|c|c|}
\hline $\begin{array}{l}\text { Dependent Variable: LOG(TP/LL) } \\
\text { Method: Least Squares } \\
\text { Sample: } 1100 \\
\text { Included observations: } 100\end{array}$ & & & & \\
\hline Variable & Coefficient & Std. Error & t-Statistic & Prob. \\
\hline $\begin{array}{l}\mathrm{LOG}(\mathrm{BB} / \mathrm{LL}) \\
\mathrm{LOG}(\mathrm{PP} / \mathrm{LL})\end{array}$ & $\begin{array}{l}0.446898 \\
0.327148\end{array}$ & $\begin{array}{l}0.068618 \\
0.063803\end{array}$ & $\begin{array}{l}6.512788 \\
5.127474\end{array}$ & $\begin{array}{l}0.0000 \\
0.0000\end{array}$ \\
\hline $\begin{array}{l}\text { R-squared } \\
\text { Adjusted R-squared } \\
\text { S.E. of regression } \\
\text { Sum squared resid } \\
\text { Log likelihood } \\
\text { Durbin-Watson stat }\end{array}$ & $\begin{array}{r}0.732252 \\
0.729520 \\
0.269155 \\
7.099563 \\
-9.637004 \\
1.754857\end{array}$ & \multicolumn{2}{|c|}{$\begin{array}{l}\text { Mean dependent var } \\
\text { S.D. dependent var } \\
\text { Akaike info criterion } \\
\text { Schwarz criterion } \\
\text { Hannan-Quinn criter. }\end{array}$} & $\begin{array}{l}11.12035 \\
0.517529 \\
0.232740 \\
0.284843 \\
0.253827\end{array}$ \\
\hline
\end{tabular}

$\mathrm{LOG}(\mathrm{TP} / \mathrm{LL})=0,4469 \mathrm{LOG}(\mathrm{BB} / \mathrm{LL})+0,3271 \mathrm{LOG}(\mathrm{PP} / \mathrm{LL}) \ldots \ldots \ldots \ldots \ldots \ldots \ldots$.

When viewed from the average tomato product per area of land is determined by the cost of tomato seeds per area of land plus the amount of fertilizer given to tomato plants per area of land. The results of this study indicate that the average tomato production per area is affected by the cost of seeds per area of 0.4469 and fertilizer cost per area of 0.3271 . Thus it can be said that the average production of tomatoes based on the land area together has an effect of 0.7323 or $73.23 \%$. The average of tomato production in tomato product average per area is 11,12 ton with standard deviation value equal to 0,52 . This means showing the tendency of tomato production of Nagari Salayo Tanang Bukik Sileh to be between 10,60-11,12 tons. So if small tomato production from 10,60 ton in per area of land, hence can be said that the land is low level of fertility in producing.

Then, the elasticity of production factor is still small from 1 that is equal to 0.774 . It means still decreasing return to scale (DRTS). Therefore, tomato farmers in Nagari Salayo Tanang Bukik Sileh still need to increase their production capability by coaching and counseling in the development of input factor in order to change into increasing return to scale (IRTS).

\section{Conclusion}

Total Production of tomatoes in Nagari Salayo Tanang Bukik Sileh is influenced by the area farmed by farmers and also influenced by the amount of Tomato Seeds Cost and the cost of fertilizer. The results showed that total tomato production was positively influenced by land area and seed cost and influenced by fertilizer cost. So, the determinant input factor is seeds then fertilizer and new land area.

How to reach the optimum tomato production level by product downstream in Nagari Salayo Tanang Bukik Sileh Lembang Jaya Subdistrict of Solok Regency can be done as planned. This is what will be created Model Development Planning Center of Environmentally Tomato Production in this 
Region. So farmers will not think for the market and not be wary of farming, because there is already a market guarantee to accommodate the production of tomatoes from the harvest.

\section{References}

Ajibefun, I. . (2006). Cropping System. Technical efficiency and policy options: A Stochastic Frontier Analysis ofNigerian small-scale farmers. Q. J. Int. Agric., 45, 145-169.

Altieri A., M. (1992). Sustainable Agrecultural Development in Latin America: exploring the possibilies. Elsivier Science Publisher.

Amerasinghe, P., Bhardwaj, R. M., Scott, C., Jella, K., \& Marshall, F. (2013). Urban wastewater and agricultural reuse challenges in India. IWMI Research Report, 147, 1-28.

Ardi, Z., \& Yendi, F. M. (2017). Students Attitude Towards LGBTQ; the Future Counselor Challenges. Jurnal Konseling Dan Pendidikan, 5(2), 74-79.

Ardi, Z., Yendi, F. M., \& Ifdil, I. (2013). Konseling Online: Sebuah Pendekatan Teknologi Dalam Pelayanan Konseling. Jurnal Konseling Dan Pendidikan, 1(1), 1-5.

Azhar, Zul, U. N. P. (2013). Perencanaan Pembangunan (Konsep, Teori, Model, teknik, Aplikasi).

Bamji, M. S. (2000). Diversification of agriculture for human nutrition. Curr. Sci.

Barron, M. A., \& Rello, F. (2000). The impact of the tomato agroindustry on the rural poor in Mexico. Agricultural Economics, 23(3), 289-297. https://doi.org/10.1016/S0169-5150(00)00090-6

Brévault, T., \& Bouyer, J. (2014). From integrated to system-wide pest management: Challenges for sustainable agriculture. Outlooks on Pest Management, 25(3), 212-213. https://doi.org/10.1564/v25_jun_05

Daharnis, D., Ardi, Z., \& Ifdil, I. (2018). The Improved of Counselor Competencies through Scientific Article Writing Training Using Digital Citation Application. Jurnal Konseling Dan Pendidikan, 6(1), 15.

Devendra, C. (2013). Systems perspectives in agricultural education, research and development: A vision for sustaining food security in Asia. ASM Science Journal, 7(2), 152-165.

Gbanie, S. P., Griffin, A. L., \& Thornton, A. (2018). Impacts on the urban environment: Land cover change trajectories and landscape fragmentation in post-war Western Area, Sierra Leone. Remote Sensing, 10(1). https://doi.org/10.3390/rs10010129

Gelcer, E., Fraisse, C. W., Zotarelli, L., Stevens, F. R., Perondi, D., Barreto, D. D., ... Southworth, J. (2018). Influence of El Niño-Southern oscillation (ENSO) on agroclimatic zoning for tomato in Mozambique. Agricultural and Forest Meteorology, 248, 316-328. https://doi.org/10.1016/j.agrformet.2017.10.002

Keatinge, J. D. H., Wang, J.-F., Dinssa, F. F., Ebert, A. W., Hughes, J. D. A., Stoilova, T., ... Ravishankar, M. (2015). Indigenous vegetables worldwide: Their importance and future development. Acta Horticulturae, 1102, 1-20. https://doi.org/10.17660/ActaHortic.2015.1102.1

Kumar, V., Jat, H. S., Sharma, P. C., Balwinder-Singh, Gathala, M. K., Malik, R. K., ... McDonald, A. (2018). Can productivity and profitability be enhanced in intensively managed cereal systems while reducing the environmental footprint of production? Assessing sustainable intensification options in the breadbasket of India. Agriculture, Ecosystems and Environment, 252, 132-147. https://doi.org/10.1016/j.agee.2017.10.006

Kusadokoro, M., Kagami, S., \& Senda, T. (2016). Self-production of mulberry leaves and market participation of sericulture farmers in Prewar Japan. Studies in Regional Science, 46(3), 281-293. https://doi.org/10.2457/srs.46.281

Len, P., Oleniacz, G., Skrzypczak, I., \& Mika, M. (2017). Methodology for Assessing the Size and Liquidation of the Outer Patchwork of Land (Vol. 95). Presented at the IOP Conference Series: Earth and Environmental Science. https://doi.org/10.1088/1755-1315/95/3/032020 
Lischeid, G. (2014). Landscape hydrology of rural areas: Challenges and tools. Environmental Science and Engineering (Subseries: Environmental Science), (202979), 107-113. https://doi.org/10.1007/978-3319-01017-5_5

Manyong, V.M.; Ikpi, A.; Olayemi, J.K.; Yusuf, S.A.; Omonona, B. T. . O., \& V.; Idachaba, F. S. (2005). Agriculturein Nigeria: Identifying Opportunities for Increased Commercialization and Investment. .. IITA PublicationSeries: Ibadan, Nigeria, 159.

Montgomery, F. A., Reid, S. M., \& Mandrak, N. E. (2018). A habitat-based framework to predict the effects of agricultural drain maintenance on imperiled fishes. Journal of Environmental Management, 206, 1104-1114. https://doi.org/10.1016/j.jenvman.2017.11.087

Muriu-Ng'ang'a, F. W., Mucheru-Muna, M., Waswa, F., \& Mairura, F. S. (2017). Socio-economic factors influencing utilisation of rain water harvesting and saving technologies in Tharaka South, Eastern Kenya. Agricultural Water Management, 194, 150-159. https://doi.org/10.1016/j.agwat.2017.09.005

Rattalino, E., Mourtzinis, S., Conley, S. P., Roth, A. C., Ciampitti, I. A., Licht, M. A., ... Grassini, P. (2017). Assessing causes of yield gaps in agricultural areas with diversity in climate and soils Agricultural and Forest Meteorology, 247, 170-180. https://doi.org/10.1016/j.agrformet.2017.07.010

Rimos, S., Hoadley, A. F. A., \& Brennan, D. J. (2015). Resource depletion impact assessment: Impacts of a natural gas scarcity in Australia. Sustainable Production and Consumption, 3, 45-58. https://doi.org/10.1016/j.spc.2015.08.003

Singh, S. (2000). Contract farming for agricultural diversification in the India Punjab: A study of performance andproblems. Indian J. Agric. Econ. 2.

Van den Berg, M.M.; Hengsdijk, H.; Wolf, J.; Ittersum, M.K.V.; Guanghuo, W. ., \& Roetter, R. . (2007). The impact of increasing farm size and mechanization on rural income and rice production in Zhejiang province. China. Agric. Syst.

Warziniack, T. (2014). A general equilibrium model of ecosystem services in a river basin. Journal of the American Water Resources Association, 50(3), 683-695. https://doi.org/10.1111/jawr.12211

Williams, D. R., Alvarado, F., Green, R. E., Manica, A., Phalan, B., \& Balmford, A. (2017). Land-use strategies to balance livestock production, biodiversity conservation and carbon storage in Yucatán, Mexico. Global Change Biology, 23(12), 5260-5272. https://doi.org/10.1111/gcb.13791

Yaron, G. (1998). Alternative Land Use Options in the Mount Cameroon Region: An Economic Analysis. The Centre for Social and Economic Research on the Global Environment.

Yildiz, H., Duhadway, S., Narasimhan, R., \& Narayanan, S. (2016). Production planning using evolving demand forecasts in the automotive industry. IEEE Transactions on Engineering Management, 63(3), 296-304. https://doi.org/10.1109/TEM.2016.2560162 